\title{
PERAN MEDIASI STRES KERJA PADA PENGARUH KONFLIK PEKERJAAN- KELUARGA TERHADAP KEPUASAN KERJA KARYAWAN
}

\author{
Ni Made Rai Christina Kusuma Dewi ${ }^{1}$ \\ I Gusti Ayu Dewi Adnyani ${ }^{2}$ \\ ${ }^{1,2}$ Fakultas Ekonomi dan Bisnis Universitas Udayana, Bali, Indonesia \\ email: maderai698@gmail.com
}

\begin{abstract}
ABSTRAK
Tujuan penelitian ini adalah untuk mengetahui pengaruh konflik pekerjaan keluarga dan stres kerja terhadap kepuasan kerja karyawan. Penelitian ini dilakukan di Perusahaan Hotel Puri Saron Denpasar. Jumlah sampel yang diambil sebanyak 40 orang karyawan, dengan metode sampel jenuh. Pengumpulan data dilakukan melalui wawancara dan observasi. Teknik analisis yang digunakan adalah analisis jalur, uji asumsi klasik dan uji sobel. Hasil penelitian menunjukkan bahwa konflik pekerjaan- keluarga berpenaruh positif dan signifikan terhadap stres kerja pada Hotel Puri Saron Denpasar, stres kerja berpengaruh negatif dan signifikan terhadap kepuasan kerja, konflik pekerjaan- keluarga berpengaruh negatif dan signifikan terhadap kepuasan kerja dan secara signifikan stres kerja mampu memediasi pengaruh konflik pekerjaan- keluarga terhadap kepuasan kerja. Upaya meningkatkan kepuasan kerja karyawan, pemimpin hendaknya mampu memperhatikan kemampuan karyawan dalam menyelesaikan masalah dalam pekerjaan agar tidak menimbulkan konflik antara pekerjaankeluarga pada karyawan dan memperhatikan beban waktu pekerjaan pada karyawan agar tidak menimbulkan mudah lelah pada saat bekerja sehingga mengakibatkan stres kerja yang tinggi.
\end{abstract}

Kata Kunci : konflik pekerjaan- keluarga, stres kerja, kepuasan kerja

\begin{abstract}
The purpose of this study was to determine the effect of family work conflict and work stress on employee job satisfaction. This research was conducted at the Puri Saron Hotel Company in Denpasar. The number of samples taken was 40 employees, using the saturated sample method. Data collection is done through interviews and observations. The analysis technique used is path analysis, classic assumption test and multiple test. The results showed that workfamily conflict had a positive and significant effect on job stress in Puri Saron Hotel Denpasar, work stress had a negative and significant effect on job satisfaction, work-family conflict had a negative and significant effect on job satisfaction and significantly job stress was able to mediate the effect work-family conflict with job satisfaction. Efforts to improve employee job satisfaction, leaders should be able to pay attention to the ability of employees to solve problems at work so as not to cause conflicts between work-family and employees and pay attention to the work load on employees so as not to cause fatigue at work so as to cause high work stress.
\end{abstract}

Keywords: work-family conflict, job stress, job satisfaction 


\section{PENDAHULUAN}

Sumber daya manusia merupakan kemampuan potensial yang dimiliki oleh manusia yang terdiri dari kemampuan berpikir, berkomunikasi, bertindak, dan bermoral untuk melaksanakan suatu kegiatan baik bersifat teknis maupun manajerial (Ardana dkk., 2011:5). Manajemen sumber daya manusia lebih menfokuskan mengenai peraturan peranan manusia dalam mewujudkan tujuan yang optimal (Hasibuan, 2013 : 10) Manajemen sumber daya manusia menganggap bahwa karyawan adalah kekayaan (asset) utama organisasi yang harus dipelihara dengan baik, hal ini berarti karyawan adalah faktor produksi yang harus diberdayakan secara produktif sehingga perlu bagi perusahaan untuk tetap menjaga kepuasan kerja dari karyawan.

Kepuasan kerja merupakan cara dari individu merasakan pekerjaan yang dihasilkan terhadap berbagai aspek yang terdapat dalam suatu pekerjaan (Suwanto \& Priansa, 2016:263). Kepuasan kerja dianggap sebagai sesuatu yang penting sebab karyawan dalam sebuah organisasi merupakan faktor yang dominan keberadaaanya dalam menentukan berhasil atau tidaknya kegiatan organisasi (Yasa \& Dewi, 2018). Situasi dan sikap karyawan terhadap pekerjaan biasanya akan menentukan kepuasan kerja sehingga jikalau seorang karyawan mengalami konflik antara keluarga dengan pekerjaan dapat mempengaruhi kepuasan kerja (Yani et al., 2016) Konflik pekerjaan-keluarga juga dapat mempengaruhi seseorang untuk mengalami stres dalam pekerjaannya (Rabenu et al., 2017) selain itu juga menurut Yasa \& Dewi (2018) stres kerja dapat mempengaruhi perasaan seseorang terhadap pekerjaan mereka atau kepuasan mereka dalam bekerja.

Teori Dua Faktor Herzberg adalah salah satu teori yang banyak dikutip dalam menjelaskan kepuasan kerja. Teori ini menjelaskan mengenai dua faktor yang menyebabkan adanya perasaan puas dan tidak puas pada suatu pekerjaan yaitu hygiene factor dan motivational factor. Hygiene factor berbicara mengenai hal yang mencakup status seseorang dalam organisasi dan motivational factor berbicara mengenai hal yang mendorong seseorang untuk berprestasi secara intrinsik. Salah satu motivational factor adalah pekerjaan itu sendiri, yang merupakan salah satu penyebab dari terciptanya kepuasan kerja (Robbins \& Judge, 2008:110) . Berdasarkan penelitian yang dilakukan oleh Yani et al. (2016) menyatakan bahwa konflik pekerjaan- keluarga dapat mempengaruhi kepuasan kerja secara negatif signifikan. Konflik pekerjaan- keluarga terjadi ketika karyawan membawa masalah dan tekanan dari pekerjaan ke rumah akan mempengaruhi kualitas dari kehidupan keluarga dan hal ini juga dapat terjadi ketika tanggung jawab keluarga menganggu tugas- tugas terkait pekerjaan individu (Ru Hsu, 2011). Konflik pekerjaan- keluarga akan berhubungan langsung lebih kuat dengan depresi dan kegelisahan (Roboth, 2015). Kegelisahan merupakan salah satu penyebab terjadinya stres (Qureshi, 2012). Konflik pekerjaan- keluarga yang terjadi dapat meningkatkan stres dalam pekerjaannya (Rabenu et al., 2017). Greenhaus \& Beutell (1985) menyatakan bahwa melaksanakan pekerjaan di tempat kerja menjadi terasa sulit pada saat berbenturan dengan tuntutan di rumah dan mengatasi pekerjaan di rumah akan terasa sulit saat adanya tekanan di tempat kerja.

Soeharto (2010) menyatakan karyawan yang memiliki konflik pekerjaankeluarga yang tinggi akan mengalami ketidakpuasan terhadap pekerjaan dari pada 
karyawan yang mengalami konflik pekerjaan- keluarga yang rendah. Perbedaan antara sejarah, struktur, budaya dan adat istiadat yang dimiliki oleh suatu daerah, menuntut untuk melaksanakan peran yang berbeda bahkan lebih kompleks. Ketika pekerjaan menganggu kehidupan keluarga, seseorang memiliki waktu dan energi yang terbatas dalam memenuhi tuntutan peran dalam keluarga, sehingga akan mengakibatkan lebih banyak tekanan atau ketidakpuasan dalam keluarga maupun sebaliknya. Berdasarkan penelitian sebelumnya oleh (Ng et al., 2016) menyatakan bahwa konflik pekerjaan keluarga berhubungan negatif dengan kepuasan kerja sama halnya dengan hasil penelitian yang dilakukan oleh (Ru Hsu, 2011) dengan petugas tahanan yang menunjukkan hasil bahwa konflik pekerjaan keluarga memiliki hubungan negatif pada kepuasan kerja. Hal ini berarti apabila karyawan memiliki konflik pekerjaan keluarga maka dapat menurunkan tingkat kepuasan kerja karyawan. Selain menyebabkan ketiadakpuasan, penelitian sebelumnya yang dilakukan oleh (Rabenu et al., 2017) menunjukkan bahwa karyawan yang mengalami konflik pekerjaan- keluarga dapat menyebabkan stres dalam pekerjaannya.

Stres dapat timbul akibat adanya tekanan yang bersumber dari ketidakselarasan seseorang dengan lingkungannya (Ariana \& Riana, 2016). Stres merupakan permasalahan utama yang paling sulit untuk dihindari dalam bekerja disuatu organisasi (Parvaiz et al., 2015). Stres kerja merupakan kondisi dimana seseorang mengalami perubahan emosi, proses berpikir, dan kondisi secara tertentu (Hlatywayo et al., 2014). Berdasarkan hasil analisis penelitian yang dilakukan oleh Yasa \& Dewi (2018) menunjukkan bahwa stres kerja dapat mempengaruhi kepuasan kerja karyawan. Ariana \& Riana (2016) menyatakan adanya hubungan yang negatif antara stres kerja dengan kepuasan kerja, hal ini berarti menandakan semakin tinggi stres kerja yang dirasakan karyawan, maka kepuasan kerja karyawan akan menurun.

Penelitian sebelumnya oleh Singh \& Nayak (2015) menyatakan bahwa stres kerja memediasi hubungan antara konflik pekerjaan -keluarga dan kepuasan kerja. Ini berarti stres kerja mempengaruhi hubungan antara konflik pekerjaan -keluarga dengan kepuasan kerja menjadi hubungan yang tidak langsung.

Pulau Bali merupakan salah satu tujuan wisatawan mancanegara. Wisatawan mancanegara yang berkunjung ke daerah Bali pada bulan Maret 2019 mencapai 499. 637 kunjungan, jumlah ini mengalami peningkatan dibandingkan dengan bulan sebelumnya sebesar 2,77 \% namun angka ini berfluktuasi dari bulan ke bulan (BPS, 2019). Hal ini menjadi perhatian bagi industri pariwisata di daerah Bali termasuk di dalamnya salah satu penyedia layanan akomodasi para wisatawan yang datang ke Bali, Hotel Puri Saron Denpasar yang beralamat di Jl. Gatot Subroto Barat 459 C Denpasar. Hotel Puri Saron Denpasar dituntut untuk memenuhi standar tertentu dalam pelayanan yang dilakukan karyawan agar mampu bersaing dalam industri pariwisata.

Karyawan yang memiliki kepercayaan terhadap nilai dan kompetensi dasar mereka akan merasa lebih puas dengan pekerjaannya dibandingkan dengan karyawan yang tidak memiliki kepercayaan terhadap nilai dan kompetensi dasar (Robbins \& Judge, 2015:52). Adanya keluhan atau aspirasi dari karyawan merupakan salah satu respon dari seorang karyawan terhadap ketidakpuasan pada 
pekerjaan mereka (Robbins \& Judge, 2015). Terdapat indikasi mengenai ketidakpuasan kerja pada Hotel Puri Saron Denpasar yaitu adanya keluhan- keluhan dan diskusi bersama antara pegawai dan pihak HRD mengenai masalah yang menyebabkan ketidakpuasan kerja yaitu permasalahan mengenai tekanan pekerjaan karyawan baik itu bersumber dari lingkungan pekerjaan maupun diluar (keluarga). Tekanan dan ketegangan yang bersumber dari ketidakselarasan antara seseorang dengan lingkungannya (pekerjan dan diluar pekerjaan) dapat menimbulkan stres kerja pada karyawan (Siagian, 2015: 300). Adanya indikasi terhadap ketidakpuasan karyawan pada Hotel Puri Saron dapat dilihat dari data turnover yang disajikan pada tabel 1 .

Tabel 1.

Data Turnover Karyawan Hotel Puri Saron Denpasar 2018-2019

\begin{tabular}{|c|c|c|c|c|c|}
\hline Tahun & $\begin{array}{c}\text { Jumlah } \\
\text { Karyawan } \\
\text { Awal } \\
\text { Tahun } \\
\text { (orang) } \\
\text { (1) } \\
\end{array}$ & $\begin{array}{c}\text { Jumlah } \\
\text { Karyawan } \\
\text { Akhir } \\
\text { Tahun } \\
\text { (orang) } \\
(2) \\
\end{array}$ & $\begin{array}{c}\text { Jumlah } \\
\text { Karyawan } \\
\text { Masuk } \\
\text { (orang) } \\
\text { (3) }\end{array}$ & $\begin{array}{l}\text { Jumlah } \\
\text { Karyawan } \\
\text { Keluar } \\
\text { (orang) } \\
(4) \\
\end{array}$ & $\begin{array}{c}\text { Turnover Karyawan } \\
\frac{q}{((1)+(Z) / Z} \times 1 \quad \% \\
(5)\end{array}$ \\
\hline 2018 & 43 & 43 & 6 & 6 & $13,95 \%$ \\
\hline 2019 & 43 & 40 & 4 & 7 & $16,86 \%$ \\
\hline
\end{tabular}

Sumber: Data diolah, 2019

(Robbins \& Judge, 2008:111) menyatakan bahwa konsekuensi ketidakpuasan kerja adalah keluar (exit) yang merupakan perilaku karyawan yang ditujukan untuk meninggalkan organisasi termasuk mencari posisi baru dan mengundurkan diri. Berdasarkan data turnover di atas dapat menunjukkan tingginya tingkat perputaran karyawan. Pada tahun 2017 terdapat 6 karyawan yang keluar dan pada tahun 2018 terdapat 8 karyawan yang keluar dari pekerjaannya. Selain menunjukkan adanya konsekuensi ketidakpuasan yaitu keluar juga dapat menunjukkan rendahnya loyalitas dari karyawan.

Berdasarkan keterangan dari 10 karyawan sebagian besar merasa kesulitan untuk mengatur perubahan jadwal pada karyawan lain apabila karyawan tersebut mengalami hal mendesak untuk keperluan keluarga seperti halnya upacara adat dan menyama braya (kegiatan kebersamaan dan persaudaraan di Bali) sehingga karyawan harus mengatur waktu dengan sangat tepat agar kedua peran baik sebagai karyawan maupun sebagai anggota keluarga dapat berjalan dengan baik. Namun terkadang hal ini dapat menyebabkan adanya beberapa permasalahan seperti keterlambatan dalam bekerja. Selain itu juga seperti pada umumnya, hotel adalah salah satu perusahaan yang beroperasi dan melaksanakan pelayanan selama 24 jam. Sehingga bagi seorang karyawan terutama karyawan perempuan akan merasa sulit untuk meninggalkan keluarga terutama seorang anak jikalau harus mendapatkan jadwal kerja pada malam hari. Hal ini terutama dirasakan oleh karyawan perempuan yang mempunyai anak balita yang harus mendapatkan perhatian khusus.

Keadaan karyawan yang harus memilih antara pekerjaan dan keluarga dapat menyebabkan tekanan bagi mereka dalam bekerja. Tekanan merupakan salah satu indikator penyebab terjadinya stres kerja. Hal ini menjadi penyebab karyawan mengalami stres kerja dari faktor pribadi. Berdasarkan wawancara dengan HRD, 
beberapa karyawan mengalami tekanan terutama bagi yang berkeluarga yang harus memenuhi kebutuhan dari keluarga namun juga dituntut untuk mampu menyelesaikan pekerjaan dengan baik. Selain itu adanya beban kerja yang berlebihan pada saat lembur dapat membuat karyawan merasa stres dalam bekerja.

Karyawan diduga cenderung memiliki konsentrasi yang terpecah pada saat dihadapkan pada tuntutan di rumah dan tuntutan di tempat kerja, hal ini menjadi suatu kesulitan dalam membagi diri antara tuntutan dalam keluarga dan pekerjaan. Hal ini didukung oleh (Greenhaus \& Beutell, 1985) yang menjelaskan konflik pekerjaan- keluarga merupakan suatu konflik antar peran di mana tekanan antara pekerjaan dan keluarga berada dalam situasi yang tidak kompatibel. Akibatnya melaksanakan pekerjaan di tempat kerja menjadi terasa sulit pada saat berbenturan dengan tuntutan di rumah dan mengatasi pekerjaan di rumah akan terasa sulit saat adanya tekanan di tempat kerja. Seorang wanita memiliki hubungan yang buruk dengan pasangan mereka sebagai akibat dari jadwal kerja yang menuntut dan pekerjaan yang belum selesai, stres dan konflik keluarga kerja adalah masalah umum yang dihadapi oleh sebagian besar karyawan terutama ibu yang bekerja namun memiliki anak kecil (Jamadin et al., 2015)

Penelitian yang dilakukan oleh (Rabenu et al., 2017) menunjukkan hubungan yang positif antara konflik pekerjaan- keluarga dengan stres kerja pada 120 tenaga kerja di Israel dan Arab. Penelitian yang dilakukan oleh Divara \& Rahyuda (2016) pada 53 karyawan Dinas Kebudayaan Provinsi Bali munjukkan hasil yang positif. Hal ini menunjukkan bahwa tenaga kerja yang memiliki konflik pekerjaankeluarga dapat meningkatkan stres dalam pekerjaannya. Penelitian yang dilakukan oleh Afina Murtininggrum, (2005) dan Almasitoh (2011) menunjukkan bahwa variabel konflik pekerjaan- keluarga mempunyai pengaruh positif terhadap stres kerja atau semakin besar konflik pekerjaan keluarga maka semakin meningkatkan stress kerja pada profesi .

$\mathrm{H}_{1}$ : Konflik pekerjaan- keluarga berpengaruh positif terhadap stres kerja

Yasa \& Dewi (2018) mengatakan teori kepuasan kerja berusaha mengungkapkan hal yang membuat sebagian orang lebih puas terhadap suatu pekerjaan daripada beberapa lainnya. Teori ini juga mencari landasan tentang proses perasaan orang terhadap kepuasan kerja. Kepuasan kerja merupakan pandangan karyawan yang menyenangkan atau tidak menyenangkan terhadap pekerjaan mereka Perasaan tersebut akan tampak dari sikap positif karyawan terhadap pekerjaan dan segala sesuatu yang dihadapi di lingkungan kerjanya (Handoko, 2011:193). Beban kerja yang dirasa terlalu berat seiring dengan adanya tuntutan efektivitas dan efisiensi kerja, permasalahan seperti ini yang terkadang menimbulkan stres kerja (Arnanta \& Utama, 2017)

Penelitian yang dilakukan oleh Yasa \& Dewi, (2018) menunjukkan adanya pengaruh negatif signifikan stres kerja terhadap kepuasan kerja pada 92 anggota PNS di Badan Pendapatan Daerah Kota Denpasar. Penelitian yang dilakukan oleh Wibowo et al. (2015) menyatakan bahwa karyawan yang memiliki tingkat stress yang tinggi maka akan menurunkan rasa puas karyawan terhadap pekerjaannya. Penelitian yang dilakukan oleh Ariana \& Riana (2016) mengemukakan bahwa stres kerja berpengaruh negatif terhadap kepuasan kerja. Selain itu, penelitian yang menunjukkan hasil negatif signifikan antara stres kerja terhadap kepuasan kerja 
dilakukan oleh Yani et al (2016) pada karyawan wanita di Bank Republik Indonesia (BRI). Hal tersebut menunjukkan bahwa semakin tinggi stres kerja pada karyawan maka akan menyebabkan rendahnya tingkat kepuasan kerja karyawan.

$\mathrm{H}_{2}$ : Stres kerja berpengaruh negatif terhadap kepuasan kerja

Sikap dan perasaan yang negatif terhadap pekerjaan merupakan akibat dari konflik pekerjaan- keluarga yang dialami (Soeharto, 2010). Semua sumber stres memiliki hubungan negatif yang signifikan dengan kepuasan kerja, namun koefisien konflik peran memiliki nilai tertinggi, hal ini menunjukkan bahwa konflik peran memiliki kontribusi yang besar terhadap ketidakpuasan kerja (Jahanzeb, 2010).

Penelitian yang dilakukan oleh Yani et al. (2016) menunjukkan pengaruh negatif signifikan konflik pekerjaan- keluarga terhadap kepuasan kerja pada pekerja wanita di Bank Republik Indonesia (BRI). Selain itu, penelitian yang dilakukan oleh $\mathrm{Ng}$ et al (2016) juga menunjukkan pengaruh negatif konflik pekerjaankeluarga terhadap kepuasan kerja pada petugas profesional kesehatan di Malaysia. Penelitian yang dilakukan oleh Ariana \& Riana (2016) serta Mahardika dan Dewi (2019) juga menunjukkan hasil negatif pada pengaruh konflik pekerjaan- keluarga terhadap kepuasan kerja. Hal ini menandakan bahwa semakin tinggi tingkat konflik pekerjaan- keluarga karyawan akan menurukan tingkat kepuasan kerja karyawan. $\mathrm{H}_{3}$ : Konflik pekerjaan- keluarga berpengaruh negatif terhadap kepuasan kerja

Hasil penelitan yang dilakukan oleh Singh \& Nayak (2015) pada 599 petugas kepolisian di New Delhi India mengungkapkan bahwa stres memediasi hubungan antara konflik pekerjaan- keluarga dengan kepuasan kerja petugas kepolisian. Hal ini menandakan bahwa stres mampu memediasi pengaruh kepuasan kerja- karyawan terhadap kepuasan kerja. Ardita et al. (2018) dan Ru Hsu (2011) mengungkapkan bahwa stres kerja memediasi hubungan antara konflik pekerjaan keluarga dengan kepuasan kerja. Jika karyawan merasakan konflik pekerjaankeluarga maka secara tidak langsung mengalami tekanan atau stres dalam pekerjaannya dan kemudian merasa tidak puas dengan pekerjaannya.

$\mathrm{H}_{4}$ : Stres kerja memediasi pengaruh konflik pekerjaan- keluarga terhadap kepuasan kerja

Robbins dan Judge (2015:49) menyatakan bahwa kepuasan kerja menjelaskan mengenai sikap pekerja yang dihasilkan dari suatu evaluasi pada pekerjaannya. Tingkat kepuasan karyawan akan berdampak pada perasaan karyawan. Karyawan yang memiliki tingkat kepuasan yang tinggi pada pekerjaanya akan memiliki perasaan yang positif kepada pekerjaaanya, sedangkan seorang yang memiliki tingkat kepuasan yang rendah akan memiliki perasaan negatif (Robbins \& Judge, 2015:49).

Kepuasan kerja menunjukkan adanya suatu keselarasan antara harapan dan kenyataan tentang pekerjaanya. Kepuasan kerja dapat berlaku bagi suatu individu ataupun kelompok. Robbins dan Judge (2015:50) mengatakan dari segi kepuasan kerja, menikmati pekerjaan itu sendiri hampir selalu menjadi segi yang paling berkaitan erat dengan tingkat kepuasan kerja yang tinggi jika dilihat secara keseluruhan. Zorlu (2012) menyatakan bahwa kepuasan kerja juga mencakup faktor fisik dan psikologis yang disebabkan oleh kondisi tempat kerja dan oleh manajemen dan pendekatan kerja di perusahaan. Rivai (2014:856) menyimpulkan bahwa 
kepuasan kerja merupakan evaluasi yang menggambarkan seseorang atas perasaan sikapnya senang atau tidak senang, puas atau tidak puas dalam bekerja.

Ivancevich et al. (2007)menyatakan kepuasan adalah sesuatu perasaan yang dialami oleh seseorang, dimana apa yang diharapkan telah terpenuhi atau bahkan apa yang diterima melebihi apa yang diharapkan, sedangkan kerja merupakan usaha seseorang untuk mencapai tujuan dengan memperoleh pendapatan atau kompensasi dari kontribusinya kepada tempat pekerjaannya. Luthans (2006) menyatakan bahwa kepuasan kerja adalah suatu emosi yang merupakan respon terhadap situasi kerja, sehingga kepuasan kerja tidak dapat dilihat namun bisa dirasakan dan akan tercermin dalam sikap seperti semakin loyal pada organisasi, bekerja dengan maksimal, dan mematuhi peraturan yang dibuat dalam organisasi.

Greenhaus \& Beutell (1985) menyatakan konflik pekerjaan- keluarga adalah suatu bentuk konflik antar peran yang mana tekanan peran dari pekerjaan dan keluarga tidak kompatibel. Konflik pekerjaan- keluarga merupakan suatu bentuk konflik di mana tekanan peran dari pekerjaan dan keluarga saling berbenturan . Konflik pekerjaan-keluarga berarti konflik yang terjadi akibat konflik peran antara pekerjaan dan keluarga yang saling terkait. Hal ini dapat terjadi jika kontribusi karyawan dalam perannya di perusahaan menciptakan masalah dalam kontribusinya pada peran keluarga. Konflik pekerjaan- keluarga terjadi ketika karyawan membawa masalah dan tekanan dari pekerjaan ke rumah yang secara negatif memengaruhi kualitas kehidupan keluarga dan terjadi ketika tanggung jawab keluarga mengganggu tugas-tugas terkait pekerjaan individu (Ru Hsu, 2011). Karakteristik pekerjaan meliputi masa kerja di organisasai, sifat organisasi, pendapatan dan tingkat otonomi sedangkan karakteristik keluarga seperti jumlah anak, usia anak, jumlah tanggungan, usia tanggungan, status perkawinan dan pekerjaan pasangan (Ramasundaram \& Ramasundaram, 2011)

Hanif \& Naqvi (2014) menyatakan seseorang secara aktif melaksanakan pekerjaan dan keluarga mengakibatkan mereka memiliki peran ganda, peran dalam pekerjaan (sebagai seorang karyawan) dan peran dalam keluarga (sebagai suami, istri dan orang tua). Menyeimbangkan peran antara keluarga dan pekerjaan merupakan cara untuk meminimalkan konflik yang akan terjadi (Jennifer et al., 2005). Christine dkk. (2010) menyatakan konflik pekerjaan- keluarga merupakan akibat dari sulitnya menyeimbangkan urusan pekerjaan dan keluarga, dimana urusan pekerjaan menganggu kehidupan keluarga dan atau urusan keluarga mengganggu kehidupan pekerjaan yang pada akhirnya dapat mempengaruhi kinerja seseorang yang bekerja.

Robbins \& Judge (2008:368)mengatakan stres adalah suatu kondisi dinamis di mana seorang individu dihadapkan pada peluang, tuntutan, atau sumber daya yang terkait dengan yang dihasratkan oleh individu itu dan yang hasilnya dipandang tidak pasti dan penting. Sebagian besar orang menyadari bahwa stres karyawan merupakan suatu masalah yang semakin banyak dijumpai dalam organisasi. Stres tercipta karena ketidakseimbangan antara tanggung jawab kerja dan keluarga. Stres merupakan akibat dari setiap tindakan dan situasi lingkungan yang menimbulkan tuntunan psikologis dan fisik yang berlebihan pada seseorang (Sunyoto, 2015:54).

Stres tidak selamanya buruk. Meskipun terkadang dibahas dalam konteks negatif, stres juga memiliki nilai positif. Stres akan menjadi suatu peluang ketika 
stres menawarkan potensi hasil. Orang- orang semacam ini secara positif memanfaatkan stres untuk menangkap peluang dan berkinerja dengan atau mendekati tingkat kemampuan maksimum mereka. Stres merupakan suatu kondisi di mana karyawan yang sedang memiliki ketegangan yang mempengaruhi emosi, proses bepikir, dan kondisi seseorang (Hasibuan, 2011:204).

Jamadin et al. (2015) menyatakan bahwa ketidaksanggupan seseorang dalam mengatasi suatu tekanan dalm pekerjaannya dapat dikatakan sebagai stres. Dalam keadaan stres atau mempersiapkan untuk menghindari stres maka yang dapat dilakukan adalah menerapkan sumber daya tuntutan seperti siap, menempatkan penilaian dalam perspektif yang benar, atau mendapatkan dukungan sosial maka tingkat stres akan lebih rendah. Stres kerja adalah perasaan tertekan yang dialami karyawan dalam menghadapi pekerjaan (Saputra \& Adnyani, 2018). Al Khalidi \& Wazaify (2013) mengatakan bahwa pemicu stres adalah ketidakjelasan dari apa yang menjadi tanggungjawab pekerjaan, kekurangan waktu dalam penyelesaian tugas, kurangnya fasilitas untuk menjalankan pekerjaan, dan tugas yang bertentangan.

\section{METODE PENELITIAN}

Penelitian ini berlokasi di Hotel Puri Saron Denpasar yang beralamat di Jl. Gatot Subroto Barat 459 C, Denpasar, Bali, Indonesia. Lokasi penelitian ini dipilih karena ada beberapa masalah yang mengindikasikan adanya ketidakpuasan kerja. Objek penelitian dalam penelitian ini adalah konflik pekerjaan- keluarga, stres kerja, dan kepuasan kerja.

Populasi dalam penelitian ini adalah seluruh karyawan Hotel Puri Saron Denpasar sebanyak 40 karyawan. Sampel yang dipilih dalam penelitian ini menggunakan teknik sampling non-probability sampling yaitu teknik jenuh yaitu teknik pengambilan sampel yang menggunakan seluruh populasi sebagai sampel. Populasi pada penelitian ini berjumlah 40 orang karyawan Hotel Puri Saron Denpasar.

Analisis jalur digunakan untuk menganalisis pola hubungan antar variabel dengan tujuan untuk mengetahui pengaruh langsung maupun tidak langsung variabel eksogen terhadap variabel endogen. Dasar perhitungan koefisian jalur adalah analisis korelasi dan regresi dan dalam perhitungannya menggunakan software dengan program SPSS for windows.

\section{HASIL DAN PEMBAHASAN}

Setiap butir dalam instrument itu valid atau tidak dapat diketahui dengan cara mengkorelasikan antara skor butir dengan skor total. Instrument dikatakan valid jika korelasi antara skor faktor dengan skor total bernilai positif dan nilainya lebih dari 0,30 ( $\mathrm{r}>0,30)$ (Sugiyono, 2017:121). Tabel 2. menyajikan hasil validitas instrument penelitian. 
Tabel 2.

Hasil Uji Validitas

\begin{tabular}{|c|c|c|c|c|c|}
\hline \multirow[b]{2}{*}{ No. } & \multirow[b]{2}{*}{ Variabel } & \multicolumn{3}{|c|}{ Validitas } & \multirow[b]{2}{*}{ Keterangan } \\
\hline & & Item & $\begin{array}{l}\text { Korelasi Item } \\
\text { Total }\end{array}$ & Standar & \\
\hline \multirow[t]{5}{*}{1} & Kepuasan Kerja (Y) & $\left(\mathrm{Y}_{1.1}\right)$ & 0,795 & 0,3 & Valid \\
\hline & & $\left(Y_{1.2}\right)$ & 0,770 & 0,3 & Valid \\
\hline & & $\left(\mathrm{Y}_{1.3}\right)$ & 0,784 & 0,3 & Valid \\
\hline & & $\left(\mathrm{Y}_{1.4}\right)$ & 0,743 & 0,3 & Valid \\
\hline & & $\left(\mathrm{Y}_{1.5}\right)$ & 0,551 & 0,3 & Valid \\
\hline \multirow[t]{8}{*}{2} & Stres Kerja $(Z)$ & $\left(Z_{1.1}\right)$ & 0,826 & 0,3 & Valid \\
\hline & & $\left(Z_{1.2}\right)$ & 0,799 & 0,3 & Valid \\
\hline & & $\left(Z_{1.3}\right)$ & 0,850 & 0,3 & Valid \\
\hline & & $\left(Z_{1.4}\right)$ & 0,526 & 0,3 & Valid \\
\hline & & $\left(Z_{1.5}\right)$ & 0,576 & 0,3 & Valid \\
\hline & & $\left(\mathrm{Z}_{1.6}\right)$ & 0,800 & 0,3 & Valid \\
\hline & & $\left(Z_{1.7}\right)$ & 0,780 & 0,3 & Valid \\
\hline & & $\left(Z_{1.8}\right)$ & 0,722 & 0,3 & Valid \\
\hline \multirow[t]{8}{*}{3} & Stres Kerja (X) & $\left(\mathrm{X}_{1.1}\right)$ & 0,798 & 0,3 & Valid \\
\hline & & $\left(\mathrm{X}_{1.2}\right)$ & 0,798 & 0,3 & Valid \\
\hline & & $\left(\mathrm{X}_{1.3}\right)$ & 0,842 & 0,3 & Valid \\
\hline & & $\left(\mathrm{X}_{1.4}\right)$ & 0,683 & 0,3 & Valid \\
\hline & & $\left(\mathrm{X}_{1.5}\right)$ & 0,892 & 0,3 & Valid \\
\hline & & $\left(\mathrm{X}_{1.6}\right)$ & 0,826 & 0,3 & Valid \\
\hline & & $\left(\mathrm{X}_{1.7}\right)$ & 0,910 & 0,3 & Valid \\
\hline & & $\left(\mathrm{X}_{1.8}\right)$ & 0,954 & 0,3 & Valid \\
\hline
\end{tabular}

Sumber: Data diolah, 2019

Tabel 2. Menunjukkan bahwa seluruh indikator pernyataan dalam variabel konflik pekerjaan- keluarga, stres kerja dan kepuasan kerja memiliki korelasi item total lebih dari 0,30 sehingga seluruh indikator tersebut telah memenuhi syarat validitas data.

Suatu instrumen dikatakan reliabel, jika instrumen tersebut memiliki nilai Alpha Cronbach > 0,60 (Sugiyono, 2017:122). Adapun hasil uji reliabilitas dapat ditunjukkan pada table 3 Berikut ini:

Tabel 3.

Hasil Uji Reliabilitas

\begin{tabular}{|c|c|c|c|c|}
\hline \multirow[b]{2}{*}{ No. } & \multirow[b]{2}{*}{ Variabel } & \multicolumn{2}{|c|}{ Reliabilitas } & \multirow[b]{2}{*}{ Keterangan } \\
\hline & & $\begin{array}{c}\text { Alpha } \\
\text { Cronbach }\end{array}$ & Standar & \\
\hline 1 & Kepuasan Kerja (Y) & 0,777 & 0,6 & Reliabel \\
\hline 2 & Stres Kerja $(Z)$ & 0,883 & 0,6 & Reliabel \\
\hline 3 & Konflik Pekerjaan Keluarga (X) & 0,872 & 0,6 & Reliabel \\
\hline
\end{tabular}

Sumber: Data diolah, 2019

Hasil uji reliabilitas yang disajikan dalam Tabel 3. menunjukkan bahwa instrument penelitian yaitu konflik pekerjaan keluarga, stres kerja dan kepuasan kerja memiliki koefisien Alpha Cronbach lebih besar dari 0,6. Hal ini dapat dikatakan bahwa semua instrumen reliabel sehingga dapat digunakan untuk melakukan penelitian. 
Uji normalitas pada penelitian ini dilakukan dengan menggunakan uji Kolmogorov Smirnov di mana data yang berdistribusi normal jika Asymp Sig.(2tailed) lebih besar dari 0,05.

Tabel 4.

Hasil Uji Normalitas Struktur 1

\begin{tabular}{lc}
\hline & Unstandardized Residual \\
\hline $\mathrm{N}$ & 40 \\
Kolmogorov-Smirnov & 0,626 \\
Asymp Sig. (2-tailed) & 0,828 \\
\hline
\end{tabular}

Sumber: Data diolah, 2019

Tabel 4. menunjukkan bahwa nilai Kolmogorov-Smirnov sebesar 0,626 sedangkan nilai Asymp Sig.(2-tailed) sebesar 0,828. Hasil tersebut menunjukkan bahwa model persamaan regresi tersebut berdistribusi normal karena nilai Asymp Sig.(2-tailed) lebih besar dari $\alpha=0,05$.

Tabel 5.

Hasil Uji Normalitas Struktur 2

\begin{tabular}{lc}
\hline & Unstandardized Residual \\
\hline $\mathrm{N}$ & 40 \\
Kolmogorov-Smirnov & 0,651 \\
Asymp Sig. (2-tailed) & 0,790 \\
\hline Sumber: Data diolah, 2019
\end{tabular}

Sumber: Data diolah, 2019

Tabel 5. menunjukkan bahwa nilai Kolmogorov-Smirnov sebesar 0,651 sedangkan nilai Asymp Sig.(2-tailed) sebesar 0,790. Hasil tersebut menunjukkan bahwa model persamaan regresi tersebut berdistribusi normal karena nilai Asymp Sig.(2-tailed) lebih besar dari $\alpha=0,05$.

Uji ini digunakan untuk mengetahui ada atau tidaknya penyimpangan asumsi klasik multikolinieritas, yaitu adanya hubungan linier antar variabel eksogen dalam model regresi. Adanya multikolinieritas dapat dilihat dari nilai tolerance atau VIF. Jika nilai tolerance lebih dari 10 persen atau VIF kurang dari 10, maka dikatakan tidak ada multikolinieritas.

Tabel 6.

Hasil Uji Multikolinieritas

\begin{tabular}{lcc}
\hline \multicolumn{1}{c}{ Variabel } & Tolerance & VIF \\
\hline Konflik pekerjaan- keluarga & 0,659 & 1,518 \\
Stres kerja & 0,659 & 1,518 \\
\hline
\end{tabular}

Sumber: Data diolah, 2019

Tabel 6. menunjukkan bahwa nilai tolerance dan VIF dari variabel konflik pekerjaan keluarga dan stres kerja menunjukkan nilai tolerance untuk setiap variabel lebih besar dari 10 persen dan nilai VIF lebih kecil dari 10 yang berarti model persamaan regresi bebas dari multikolinieritas.

Uji ini digunakan untuk menguji apakah dalam model regresi terjadi ketidaksamaan varian dari residual satu pengamatan ke pengamatan yang lain. Jika nilai signifikansinya di atas 0,05 maka tidak mengandung gejala heteroskedastistas. 
Tabel 7.

Hasil Uji Heteroskedastisitas Struktur 1

\begin{tabular}{clccccc}
\hline \multicolumn{1}{c}{ Model } & \multicolumn{7}{c}{$\begin{array}{c}\text { Unstandardized } \\
\text { Coefficients } \\
\text { Std. }\end{array}$} & $\begin{array}{c}\text { Standardized } \\
\text { Coefficients }\end{array}$ & & \\
\hline 1 & $\begin{array}{c}\text { B } \\
\text { Error }\end{array}$ & Beta & t & Sig. \\
\hline & $\begin{array}{l}\text { (Constant) } \\
\text { Konflik } \\
\text { pekerjaan- } \\
\text { keluarga }\end{array}$ & 0,495 & 0,292 & & 1,695 & 0,098 \\
& $-0,027$ & 0,096 & $-0,045$ & $-0,279$ & 0,782 \\
\hline Sumber: & & & & & &
\end{tabular}

Sumber: Data diolah, 2019

Tabel 7. menunjukkan bahwa nilai signifikansi dari variabel konflik pekerjaan- keluarga sebesar 0,782. Nilai tersebut lebih besar dari 0,05 yang berarti tidak terdapat pengaruh antara variabel bebas. Dengan demikian, model penelitian ini tidak mengandung gejala heteroskedastisitas.

Tabel 8.

Hasil Uji Heteroskedastisitas Struktur 2

\begin{tabular}{|c|c|c|c|c|c|c|}
\hline \multirow[b]{2}{*}{ Model } & & \multicolumn{2}{|c|}{$\begin{array}{l}\text { Unstandardized } \\
\text { Coefficients }\end{array}$} & $\begin{array}{c}\text { Standardized } \\
\text { Coefficients }\end{array}$ & \multirow[b]{2}{*}{$\mathbf{t}$} & \multirow[b]{2}{*}{ Sig. } \\
\hline & & B & $\begin{array}{l}\text { Std. } \\
\text { Error }\end{array}$ & Beta & & \\
\hline \multirow[t]{3}{*}{1} & (Constant) & 0,320 & 0,213 & & 1,504 & 0,141 \\
\hline & $\begin{array}{l}\text { Konflik pekerjaan- } \\
\text { keluarga }\end{array}$ & 0,010 & 0,081 & 0,025 & 0,122 & 0,903 \\
\hline & Stres kerja & $-0,025$ & 0,074 & $-0,069$ & $-0,340$ & 0,736 \\
\hline
\end{tabular}

Sumber: Data diolah, 2019

Tabel 8. menunjukkan bahwa nilai signifikansi dari variabel konflik pekerjaan- keluarga sebesar 0,903 dan dari variabel stres kerja sebesar 0,736 . Nilai tersebut lebih besar dari 0,05 yang berarti tidak terdapat pengaruh antara variabel bebas. Dengan demikian, model penelitian ini tidak mengandung gejala heteroskedastisitas.

Analisis jalur digunakan untuk menentukan hubungan 3 variabel atau lebih dalam mengkorfimasi dan menolak hipotesis. Analisis jalur digunakan untuk menganalisis pola hubungan antar variabel dengan tujuan untuk mengetahui pengaruh langsung maupun tidak langsung variabel eksogen terhadap variabel endogen.

Perhitungan koefisien path dilakukan dengan analisis regresi melalui software SPSS 17.0 for Windows, diperoleh hasil yang ditunjukkan pada Tabel 9.

Hasil analisis jalur substruktural 1 seperti yang disajikan pada Tabel 9. maka persamaan strukturalnya adalah sebagai berikut.

$$
\begin{aligned}
& Z=\alpha+\beta_{1} \mathrm{X}+\mathrm{e}_{1} \ldots \ldots \ldots \\
& Z=0,975-0,584 \mathrm{X}+\mathrm{e}_{1}
\end{aligned}
$$

Hasil analisis jalur substruktural 2 seperti yang disajikan pada Tabel 10, maka persamaan strukturalnya adalah sebagai berikut.

$$
\begin{aligned}
& Y=\alpha+\beta_{2} X+\beta_{3} M+e_{2} \ldots \ldots \ldots \ldots . . \\
& Y=5,463-0,334 X-0,552 Z+e_{2}
\end{aligned}
$$


Tabel 9.

Hasil Analisis Jalur Persamaan Regresi 1

\begin{tabular}{|c|c|c|c|c|c|}
\hline \multirow[t]{2}{*}{ Model } & \multicolumn{2}{|c|}{$\begin{array}{c}\text { Unstandardized } \\
\text { Coefficients }\end{array}$} & \multirow{2}{*}{$\begin{array}{l}\text { Standardized } \\
\text { Coefficients } \\
\text { Beta }\end{array}$} & \multirow[t]{2}{*}{$\mathbf{t}$} & \multirow[t]{2}{*}{ Sig. } \\
\hline & B & Std. Error & & & \\
\hline (Constant) & 0,975 & 0,441 & & 2,213 & 0,033 \\
\hline $\begin{array}{c}\text { Konflik } \\
\text { pekerjaan- } \\
\text { keluarga (X) }\end{array}$ & 0,643 & 0,145 & 0,584 & 4,436 & 0,000 \\
\hline$R^{2}$ & & & & & 0,341 \\
\hline F Hitung & & & & & 19,675 \\
\hline Sig. F & & & & & 0,000 \\
\hline
\end{tabular}

Sumber: Data diolah, 2019

Tabel 10.

Hasil Analisis Jalur Persamaan Regresi 2

\begin{tabular}{|c|c|c|c|c|c|}
\hline \multirow[t]{2}{*}{ Model } & \multicolumn{2}{|c|}{$\begin{array}{c}\text { Unstandardized } \\
\text { Coefficients }\end{array}$} & \multirow{2}{*}{$\begin{array}{c}\text { Standardized } \\
\text { Coefficients } \\
\text { Beta } \\
\end{array}$} & \multirow[t]{2}{*}{$\mathbf{t}$} & \multirow[t]{2}{*}{ Sig. } \\
\hline & B & Std. Error & & & \\
\hline (Constant) & 5,463 & 0,319 & & 17,127 & 0,000 \\
\hline $\begin{array}{c}\text { Konflik } \\
\text { pekerjaan- } \\
\text { keluarga }(\mathrm{X})\end{array}$ & $-0,330$ & 0,122 & $-0,334$ & $-2,711$ & 0,010 \\
\hline Stres kerja $(Z)$ & $-0,496$ & 0,111 & $-0,552$ & $-4,483$ & 0,000 \\
\hline $\mathrm{R}^{2}$ & & & & & 0,631 \\
\hline F Hitung & & & & & 31,605 \\
\hline Sig. F & & & & & 0,000 \\
\hline
\end{tabular}

Sumber: Data diolah, 2019

Berdasarkan model substruktur 1 dan substruktur 2, maka dapat disusun model diagram jalur akhir. Sebelum menyusun diagram jalur akhir, terlebih dahulu menghitung nilai standar error sebagai berikut.

$$
\begin{aligned}
& \mathrm{Pe}_{\mathrm{i}}=\sqrt{1-K^{2}} \ldots \ldots \ldots \ldots \ldots \ldots \ldots \ldots \ldots \ldots \\
& \mathrm{Pe}_{1}=\sqrt{1-K 1^{2}}=\sqrt{1-0,341}=0,812 \\
& \mathrm{Pe}_{2}=\sqrt{1-K 2^{2}}=\sqrt{1-0,631}=0,607
\end{aligned}
$$

Berdasarkan perhitungan pengaruh error $\left(\mathrm{Pe}_{\mathrm{i}}\right)$ didapatkan hasil pengaruh error $\left(\mathrm{Pe}_{1}\right)$ sebesar 0,812 dan pengaruh error $\left(\mathrm{Pe}_{2}\right)$ sebesar 0,607. Hasil koefisien determinasi total adalah sebagai berikut.

$$
\begin{aligned}
\mathrm{R}^{2} \mathrm{~m} & =1-\left(\mathrm{Pe}_{1}\right)^{2}\left(\mathrm{Pe}_{2}\right)^{2} \ldots \ldots \\
& =1-(0,812)^{2}(0,607)^{2} \\
& =1-(0,659)(0,368) \\
& =1-0,243 \\
& =0,757
\end{aligned}
$$

Nilai determinasi total sebesar 0,757 mempunyai arti bahwa sebesar 75,7 persen variasi kepuasan kerja karyawan dipengaruhi oleh variasi konflik pekerjaan 
keluarga dan variasi stres kerja, sedangkan sisanya 24,3 persen dijelaskan oleh faktor lain yang tidak dimasukkan ke dalam model.

Hasil analisis pengaruh konflik pekerjaan- keluarga terhadap stres kerja diperoleh nilai Sig. $\mathrm{t}$ sebesar 0,000 dengan nilai koefisien beta 0,584. Nilai Sig. $\mathrm{t}$ $0,000 \leq 0,05$ mengindikasikan bahwa $\mathrm{H}_{0}$ ditolak dan $\mathrm{H}_{1}$ diterima. Hasil ini mempunyai arti bahwa konflik pekerjaan- keluarga berpengaruh positif terhadap stres kerja. Hasil analisis pengaruh stres kerja terhadap kepuasan kerja diperoleh nilai Sig. $t$ sebesar 0,000 dengan nilai koefisien beta $-0,552$. Nilai Sig. t 0,000 $\leq$ 0,05 mengindikasikan bahwa $\mathrm{H}_{0}$ ditolak dan $\mathrm{H}_{1}$ diterima. Hasil ini mempunyai arti bahwa stres kerja berpengaruh negatif terhadap kepuasan kerja. Hasil analisis pengaruh konflik pekerjaan- keluarga terhadap kepuasan kerja diperoleh nilai Sig. t sebesar 0,010 dengan nilai koefisien beta $-0,334$. Nilai Sig. t 0,010 $\leq 0,05$ mengindikasikan bahwa $\mathrm{H}_{0}$ ditolak dan $\mathrm{H}_{1}$ diterima. Hasil ini mempunyai arti bahwa konflik pekerjaan- keluarga berpengaruh negatif terhadap kepuasan kerja.

Hasil dari koefisien jalur pada hipotesis penelitian, maka dapat digambarkan hubungan kausal antar variabel konflik pekerjaan- keluarga (X), stres kerja (Z), dan kepuasan kerja (Y) sebagai berikut.

Tabel 11.

Rangkuman Hasil Uji

\begin{tabular}{|c|c|c|c|}
\hline $\begin{array}{c}\text { Pengaruh } \\
\text { Variabel }\end{array}$ & $\begin{array}{l}\text { Pengaruh } \\
\text { Langsung }\end{array}$ & $\begin{array}{c}\text { Pengaruh Tidak Langsung } \\
\text { Melalui Kepuasan Kerja (Z) ( } \beta_{1 \times} \\
\left.\beta_{2}\right)\end{array}$ & Pengaruh Total \\
\hline$X \rightarrow Z$ & 0,584 & - & 0,584 \\
\hline $\mathrm{Z} \rightarrow \mathrm{Y}$ & $-0,552$ & - & $-0,552$ \\
\hline$X \rightarrow Y$ & $-0,334$ & $-0,322$ & $-0,656$ \\
\hline
\end{tabular}

Sumber: Data diolah, 2019

Keterangan:

$X=$ Konflik pekerjaan- keluarga

$\mathrm{Z}=$ Stres kerja

$\mathrm{Y}=$ Kepuasan kerja

Uji Sobel merupakan alat analisis untuk menguji signifikansi dari hubungan tidak langsung antara variabel bebas dengan variabel terikat yang dimediasi oleh variabel mediator. Uji Sobel dirumuskan dan dihitung melalui aplikasi Microsoft Excel 2010. Bila nilai Z lebih besar dari 1,96 maka variabel mediator dinilai secara signifikan memediasi hubungan antara variabel terikat dan variabel bebas. Hasil Uji Sobel disajikan sebagai berikut.

$$
\begin{aligned}
& \mathrm{Z}=\frac{\mathrm{a}}{\sqrt{\mathrm{b}^{2} \mathrm{~S}_{\mathrm{a}}^{2}+\mathrm{a}^{2} \mathrm{~S}_{\mathrm{b}}^{2}+\mathrm{S}_{\mathrm{a}^{2}}^{2} \mathrm{~s}_{\mathrm{b}}^{2}}} \\
& \text { Keterangan : } \\
& \mathrm{a}=0,584 \\
& \mathrm{~S}_{\mathrm{a}}=0,145 \\
& \mathrm{~b}=0,552 \\
& \mathrm{~S}_{\mathrm{b}}=0,111
\end{aligned}
$$




$$
\begin{aligned}
Z=\frac{0,584.0,552}{\sqrt{\left(0,552^{2} 0,145^{2}\right)+\left(0,584^{2} 0,111^{2}\right)+\left(0,145^{2} 0,111^{2}\right)}} \\
\quad Z=\frac{U, 3}{U, 1} \\
Z=3,092
\end{aligned}
$$

Berdasarkan hasil perhitungan menunjukkan bahwa hasil tabulasi $\mathrm{Z}=3,092>$ 1,96 yang berarti variabel mediator yaitu stres kerja dinilai secara signifikansi memediasi hubungan antara konflik pekerjaan- keluarga terhadap kepuasan kerja karyawan.

Berdasarkan pengujian hipotesis variabel konflik pekerjaan- keluarga terhadap kepuasan kerja menyatakan bahwa dalam penelitian ini mendapatkan hasil $\mathrm{H}_{0}$ ditolak dan $\mathrm{H}_{1}$ diterima. Hasil ini mempunyai arti bahwa konflik pekerjaankeluarga berpengaruh positif dan signifikan terhadap stres kerja, ini berarti bahwa semakin tinggi tingkat konflik pekerjaan- keluarga yang dirasakan karyawan maka semakin tinggi stres kerja yang dirasakan karyawan. Tingkat stres kerja karyawan Hotel Puri Saron Denpasar dipengaruhi oleh adanya konflik pekerjaan- keluarga yang dirasakan karyawan. Tingkat konflik pekerjaan keluarga sebagian besar disebabkan oleh karyawan sering merasa pemecahan masalah yang digunakan dalam pekerjaan tidak efektif dalam menyelesaikan masalah di rumah dan karyawan sering melakukan pekerjaan pada saat weekend. Tingkat konflik pekerjaan- keluarga perlu diturunkan untuk menurunkan tingkat stres kerja yang dirasakan karyawan Hotel Puri Saron Denpasar. Hasil ini didukung penelitian yang dilakukan oleh Rabenu et al. (2017), Divara \& Rahyuda (2016) bahwa konflik pekerjaan- keluarga berpengaruh positif dan signifikan terhadap stres kerja. Penelitian Almasitoh (2011) dan Metta Astari \& Sudibya (2018) menyatakan bahwa karyawan yang memiliki tingkat konflik pekerjaan- keluarga yang tinggi akan meningkatkan perasaan stres terhadap pekerjaannya.

Berdasarkan pengujian hipotesis variabel stres kerja terhadap kepuasan kerja menyatakan bahwa dalam penelitian ini mendapatkan hasil $\mathrm{H}_{0}$ ditolak dan $\mathrm{H}_{1}$ diterima. Hasil ini mempunyai arti bahwa stres kerja berpengaruh negatif dan signifikan terhadap kepuasan kerja, ini berarti bahwa semakin tinggi tingkat stres kerja yang dirasakan karyawan maka semakin rendah tingkat kepuasan kerja karyawan. Tingkat kepuasan kerja karyawan Hotel Puri Saron Denpasar disebabkan oleh adanya stres kerja yang dirasakan karyawan. Dalam hal ini, tingkat stres kerja sebagian besar disebabkan oleh karyawan sering merasa jam kerja yang didapatkan membuat mudah lelah dan merasa mudah sakit karena tekanan dalam bekerja. Sebaiknya tingkat stres kerja perlu diturunkan untuk meningkatkan kepuasan kerja pada Hotel Puri Saron Denpasar. Penelitian ini sesuai dengan penelitian yang dilakukan oleh Yasa \& Dewi (2018), Ariana \& Riana (2016) dan Yani et al. (2016) menyatakan bahwa stres kerja berpengaruh negatif terhadap kepuasan kerja, apabila karyawan merasa tertekan dalam pekerjannya maka karyawan tersebut memiliki kepuasan kerja yang rendah. Hasil ini juga didukung penelitian yang dilakukan oleh Saputra \& Adnyani (2018) dan Wibowo et al. (2015) menyatakan bahwa ketika karyawan merasakan stres kerja yang tinggi maka kepuasan kerja karyawan rendah.

Berdasarkan pengujian hipotesis variabel konflik pekerjaan- keluarga terhadap kepuasan kerja dalam penelitian ini mendapatkan hasil $\mathrm{H}_{0}$ ditolak dan $\mathrm{H}_{1}$ 
diterima. Hasil ini mempunyai arti bahwa konflik pekerjaan- keluarga berpengaruh negatif dan signifikan terhadap kepuasan kerja, ini berarti bahwa semakin tinggi tingkat konflik pekerjaan- keluarga yang dirasakan karyawan maka semakin rendah tingkat kepuasan kerja yang dirasakan karyawan.

Tingkat kepuasan kerja karyawan Hotel Puri Saron Denpasar dipengaruhi oleh adanya konflik pekerjaan- keluarga yang dirasakan karyawan. Dalam hal ini, tingkat konflik pekerjaan- keluarga sebagian besar disebabkan karena karyawan sering merasa pemecahan masalah yang digunakan dalam pekerjaan tidak efektif dalam menyelesaikan masalah di rumah dan karyawan sering melakukan pekerjaan pada saat weekend. Sebaiknya tingkat konflik pekerjaan- keluarga karyawan perlu diturunkan untuk meningkatkan tingkat kepuasan kerja pada karyawan Hotel Puri Saron Denpasar. Penelitian ini sejalan dengan penelitian yang dilakukan oleh Yani et al. (2016), Ng et al. (2016), dan Ru Hsu (2011) menyatakan bahwa adanya pengaruh negatif antara konflik pekerjaan- keluarga dengan kepuasan kerja karyawan, bahwa karyawan yang memiliki konflik pekerjaan- keluarga yang tinggi maka karyawan tersebut akan merasakan rendahnya kepuasan kerja. Hasil ini juga sejalan dengan penelitian yang dilakukan oleh Nanda dan Utama (2015), Ariana dan Riana (2016) dan Mahardika dan Dewi (2019) menyatakan apabila karyawan yang memiliki tingkat konflik pekerjaan- keluarga yang tinggi maka akan menurunkan tingkat kepuasan kerja karyawan.

Hasil Uji Sobel didapatkan bahwa secara signifikan stres kerja memediasi pengaruh konflik pekerjaan- keluarga terhadap kepuasan kerja. Pada pengujian sebelumnya mendapatkan konflik pekerjaan- keluarga berpengaruh positif dan signifikan terhadap stres kerja dan stres kerja berpengaruh negatif dan signifikan terhadap kepuasan kerja, sehingga dapat dikatakan bahwa stres kerja secara parsial memediasi pengaruh konflik pekerjaan- keluarga terhadap kepuasan kerja. Seperti yang dinyatakan oleh Singh dan Nayak (2015) dan Armstrong et al. (2015) bahwa stres kerja memiliki efek mediasi antara konflik pekerjaan- keluarga dengan kepuasan kerja. Penelitian ini juga didukung oleh penelitian yang dilakukan Ru Hsu (2011) dan Ardita et al. (2018) yang menyatakan bahwa konflik pekerjaankeluarga memiliki dampak negatif terhadap kepuasan kerja yang dimediasi oleh stres kerja.

Hasil penelitian ini menunjukkan bahwa konflik pekerjaan- keluarga berpengaruh secara langsung terhadap kepuasan kerja, maupun secara tidak langsung melalui stres kerja. Secara teoritis, hasil penelitian ini jika dikaitkan dengan Two Factor Theory, maka dapat dikatakan perusahaan harus memperhatikan stres kerja karyawan sehingga nantinya akan menimbulkan tingginya kepuasan kerja karyawan.

Temuan penelitian ini memberikan implikasi terhadap strategi pengembangan sumber daya manusia di Hotel Puri Saron Denpasar untuk lebih memperhatikan indikator-indikator konflik pekerjaan- keluarga dan stres kerja. Terutama yang harus diperhatikan yaitu kelelahan saat bekerja, dengan cara perusahaan harus memperhatikan kemampuan dan waktu karyawan agar sesuai dengan beban pekerjaan yang ada dan pada variabel konflik pekerjaan- keluarga yang harus menjadi perhatian utama adalah pemecahan masalah yang digunakan dalam bekerja tidak efektif dalam menyelesaikan masalah yang ada di rumah, 
dengan cara memberikan pelatihan dan menerapkan budaya perusahaan dalam memecahkan masalah pada setiap karyawan. Sehingga penelitian ini diharapkan dapat digunakan sebagai bahan pertimbangan para pengambil keputusan dalam meningkatkan tingkat kepuasan kerja karyawan.

Penelitian ini memiliki beberapa keterbatasan yaitu penelitian ini hanya dilakukan pada karyawan Hotel Puri Saron Denpasar dengan melibatkan 40 orang sebagai responden, sehingga tidak bisa menggeneralisir kondisi perusahaan lain. Variabel-variabel yang digunakan pada penelitian ini hanya terbatas pada variabel konflik pekerjaan- kerja dan stres kerja dalam mengukur kepuasan kerja karyawan yang ditunjukkan dengan nilai determinasi total $\left(\mathrm{R}^{2} \mathrm{~m}\right)$ sebesar 75,7 persen. Sehingga bahwa ada variabel-variabel lain di luar model yang dapat mengukur kepuasan kerja sebesar 24,3 persen.

\section{SIMPULAN}

Konflik pekerjaan-keluarga berpengaruh positif dan signifikan terhadap stres kerja. Hal ini menunjukkan konflik pekerjaan- keluarga yang tinggi pada karyawan Hotel Puri Saron Denpasar akan menimbulkan tingginya stres kerja yang dirasakan dalam bekerja. Stres kerja berpengaruh negatif dan signifikan terhadap kepuasan kerja. Hal ini menunjukkan semakin tinggi stres kerja yang dirasakan karyawan Hotel Puri Saron Denpasar akan menurunkan tingkat kepuasan kerja karyawan. Konflik pekerjaan- keluarga berpengaruh negatif dan signifikan terhadap kepuasan kerja. Hal ini menunjukkan semakin tinggi konflik pekerjaan- keluarga yang dirasakan karyawan Hotel Puri Saron Denpasar dapat menurunkan tingkat kepuasan kerja karyawan. Stres kerja mampu memediasi pada pengaruh konflik pekerjaan- keluarga terhadap kepuasan kerja karyawan. Semakin tinggi konflik pekerjaan- keluarga yang dirasakan karyawan Hotel Puri Saron Denpasar akan menurunkan tingkat kepuasan kerja karyawan yang diperkuat dengan tingginya tingkat stres kerja yang dirasakan karyawan.

Memperhatikan mengenai konflik pekerjaan- keluarga yang dialami karyawan terhadap keefektifan karyawan dalam menyelesaikan masalah yang ada di perusahaan dan di rumah, agar melakukan pendekatan kepada keluarga karyawan terhadap perusahaan, pelatihan serta penekanan akan budaya perusahaan dalam menyelesaikan masalah sehingga karyawan mampu secara efektif untuk menyelesaikan masalah di rumah dan di perusahan dan tidak menganggu kedua peran tersebut sehingga dapat meningkatkan tingkat kepuasan karyawan. Memperhatikan jam kerja yang didapatkan oleh karyawan dalam bekerja agar membagi waktu bekerja secara adil dan memperhatikan waktu lembur karyawan. Apabila Hotel Puri Saron Denpasar dapat memperhatikan karyawannya maka akan menurunkan stres kerja karyawan yang nantinya akan berdampak pada meningkatnya tingkat kepuasan kerja karyawan. Memperhatikan balas jasa dalam bentuk finansial yang diterima karyawan, sebaiknya pihak manajemen memperhatikan mengenai keadilan antara beban pekerjaan dan keahlian agar sesuai dengan gaji yang seharusnya diterima oleh karyawan. 


\section{REFERENSI}

Al Khalidi, D., \& Wazaify, M. (2013). Assessment of Pharmacists Job Satisfaction and Job Related Stress in Amman. International Journal of Clinical Pharmacy, 35(5):821-828 https://doi.org/10.1007/s11096-013-9815-7

Almasitoh, U. H. (2011). Stres Kerja Ditinjau Dari Konflik Peran Ganda dan Dukungan Sosial Pada Perawat. Psikoislamika: Jurnal Psikologi Dan Psikologi Islam, 8(1), 63-82 https://doi.org/10.18860/psi.v0i1.1546

Ardana, K., Mujiati, W., \& Utama, W. M. (2011). Manajemen Sumber Daya Manusia. Yogyakarta: Graha Ilmu.

Ardita, Q. T., Agusdin, A., \& Furkan, L. M. (2018). Analisis Pengaruh Konflik Pekerjaan-Keluarga (work-family conflict) Dan Stres Terhadap Kepuasan Kerja Pada Karyawan Wanita Di Sekretariat Daerah (Setda) Kabupaten Di Pulau Lombok. Jurnal Magister Manajemen Universitas Mataram, 7(3), 2944 https://doi.org/10.29303/jmm.v7i3.313

Ariana, I., \& Riana, I. (2016). Pengaruh Work Family Conflict, Keterlibatan Kerja dan Stres Kerja Terhadap Kepuasan Kerja Karyawan. E-Jurnal Manajemen Universitas Udayana, 5(7), 4630-4659

Armstrong, G. S., Atkin-Plunk, C. A., \& Wells, J. (2015). The Relationship Between Work-Family Conflict, Correctional Officer Job Stress, and Job Satisfaction. Criminal Justice and Behavior, 20(10), 1-17 https://doi.org/10.1177/0093854815582221

Arnanta, I. G. P., \& I Wayan Mudiartha Utama. (2017). Pengaruh Stres Kerja, Kepuasan Kerja dan Iklim Organisasi Terhadap Turnover Intention Karyawan CV. Dharma Siadja.E-Jurnal Manajemen Unud, 6(6), 3314- 3341 https://doi.org/10.1017/CBO9781107415324.004

Badan Pusat Statistik. (2019). Perkembangan Pariwisata Bali. Maret. BPS Bali. Denpasar

Christine, W. ., Megawati, O., \& Indah, M. (2010). Pengaruh Konflik Pekerjaan dan Konflik Keluarga Terhadap Kinerja Dengan Konflik Pekerjaan Keluarga Sebagai Intervening Variabel Studi Pada Dual Career Couple di Jabodetabek. Jurnal Manajemen Dan Kewirausahaan, 12(2), 121-132.

Divara, I. G. . G. K., \& Rahyuda, A. G. (2016). Pengaruh Work Family Conflict Terhadap Stres Kerja dan Komitmen Organisasional Pegawai Kontrak Dinas Kebudayaan Provinsi Bali. E- Jurnal Manajemen Unud, 5(11), 6994-7021.

Greenhaus, J. H., \& Beutell, N. J. (1985). Sources of Conflict between Work and Family Roles. The Academy of Management Review, 10(1), 76-88 https://doi.org/10.2307/258214

Handoko, T. H. (2011). Manajemen Personalia dan Sumber Daya Manusia. Yogyakarta: BPFE Yogyakarta 
Hanif, F., \& Naqvi, S. M. M. R. (2014). Analysis of Work Family Conflict in View of Nurses, in Health Sector of Pakistan. International Journal of Gender \& Women's Studies, 2(4), 103-116 https://doi.org/10.15640/ijgws.v2n4a6

Hasibuan, M. S. P. (2011). Manajemen Sumber Daya Manusia. Jakarta: Bumi Aksara.

Hlatywayo, C. K., Zingwe, T., Mhlanga, T. S., \& Mpofu, B. D. (2014). Precursors Of Emotional Stability, Stress, And Work-Family Conflict Among Female Bank Employees. International Business \& Economics Research Journal (IBER), 13(4), 861-866 https://doi.org/10.19030/iber.v13i4.8695

Ivancevich, J. M., Konopaske, R., \& Matteson, M. . (2007). Perilaku dan Manajemen Organisasi (Ketujuh). Jakarta: Penerbit Erlangga.

Jahanzeb, H. (2010). The impact of job stress on job satisfaction among academic faculty of a mega distance learning institution in Pakistan. A case study of Allama Iqbal Open University. Mustang Journal of Business and Ethics, 119

Jamadin, N., Mohamad, S., Syarkawi, Z., \& Noordin, F. (2015). Work - Family Conflict and Stress: Evidence from Malaysia. Journal of Economics, Business and Management, 3(2), 309-312 https://doi.org/10.7763/joebm.2015.v3.200

Jennifer, D. N. B., Ofelia, R. S., Eugene, J. K., Indovino, L., \& Rosner, E. (2005). Work Family Culture, Work Family Conflict, Organizational Commitment, Job Satisfaction, and Organizational Citizenship Behavior (OCB) Among Teachers. Journal of Business and Psychology, 20(2), 303-324.

Luthans, F. (2006). Perilaku Organisasi (sepuluh). Yogyakarta: Andi.

Mahardika, I. . A., \& Dewi, A. . S. K. (2019). Pengaruh Konflik Pekerjaan Keluarga Terhadap Keinginan Keluar Melalui Mediasi Kepuasan Kerja. E- Jurnal Manajemen Unud, 8(6), 3333-3359.

Metta Astari, N. M., \& Sudibya, I. G. A. (2018). Pengaruh Work Family Conflict Terhadap Stres Kerja dan Kepuasan Kerja. E-Jurnal Ekonomi Dan Bisnis Universitas Udayana, 7(7), 1895-1927 https://doi.org/10.24843/eeb.2018.v07.i07.p05

Nanda, N. . N. K., \& Utama, I. . M. (2015). Pengaruh Konflik Kerja Keluarga dan Kepuasan Kerja Terhadap Tingkat Turnover Intention Karyawan Pada Restoran Pizza Hut Mall Bali Galeria. E- Jurnal Manajemen Unud, 4(9), 2461-2477.

Ng, L.-P., Kuar, L.-S., \& Cheng, W.-H. (2016). Influence of Work-Family Conflict and Work-Family Positive Spillover on Healthcare Professionals' Job Satisfaction. Business Management Dynamic, 5(11), 01-15

Parvaiz, L., Batool, S., Khalid, A., \& Farooqi, Y. . (2015). Impact of Stresors (Role Conflict, Role Overload, Leadership Support and Organizational Politics) On 
Job stres and its Subsequent Impact on Turnover Intention. International Journal Of Business And Management Intention, 4(10), 52-63.

Qureshi, M. I. (2012). Job Stress , Workload , Environment and Employees Turnover Intentions : Destiny or Choice. Archives Des Sciences, 65(8), 230241

Rabenu, E., Tziner, A., \& Sharoni, G. (2017). The relationship between workfamily conflict, stress, and work attitudes. International Journal of Manpower, 38(8), 1143-1156 https://doi.org/10.1108/IJM-01-2014-0014

Ramasundaram, A., \& Ramasundaram, G. (2011). The Role of Work Family Conflict as a Mediator between Work-Thought Interference and Job Stress. International Management Review, 7(2), 25-34

Rivai, V. Z. (2014). Manajemen Sumber Daya Manusia Untuk Perusahaan: Dari Teori ke Praktik (Pertama). Jakarta: PT. Raja Grafindo Persada

Robbins, S. P., \& Judge, T. A. (2008). Perilaku Organisasi (Edisi 2). Jakarta: Salemba Empat.

Robbins, S. P., \& Judge, T. A. (2015). Perilaku Organisasi (edisi 16.). Jakarta: Salemba Empat.

Roboth, J. (2015). Analisis Work Family Conflict, Stres Kerja Dan Kinerja Wanita Berperan Ganda Pada Yayasan Compassion East Indonesia. Jurnal Riset Bisnis dan Manajemen, 3(1), 33-46

Ru Hsu, Y. (2011). Work family conflict and job satisfaction in stressful working environments. International Journal of Manpower, 32(2), 233-248 https://doi.org/10.1108/01437721111130224

Saputra, M. P. P., \& Adnyani, I. G. A. D. (2018). Pengaruh Motivasi, Komunikasi dan Stres Kerja Terhadap Kepuasan Kerja Karyawan. E-Jurnal Manajemen Universitas Udayana, 8(1), 6961-6989

https://doi.org/10.24843/ejmunud.2019.v08.i01.p01

Siagian, S. P. (2015). Manajemen Sumber Daya Manusia. Jakarta : Bumi Aksara.

Singh, R., \& Nayak, J. K. (2015). Mediating Role of Stress Between Work-Family Conflict and Job Satisfaction Among The Police Officials: Moderating Role of Social Support. Policing: An International Journal Of Polices Strategies \& Management, 38(4), 738-753 https://doi.org/10.1108/PIJPSM-03-20150040

Soeharto, T. N. E. . (2010). Konflik Pekerjaan- Keluarga dengan Kepuasan Kerja: Metaanalisis. Jurnal Psikologi, 37(1), 189-194.

Sugiyono. (2017). Metode Penelitian Kuantitatif, Kualitatif, dan R\&D. Bandung: Alfabeta.

Sunyoto, D. (2015). Penelitian Sumber Daya Manusia. Jakarta: PT. Buku Seru. 
Suwanto, \& Priansa, D. J. (2016). Manajemen SDM dalam Organisasi Publik dan Bisnis. Bandung: Penerbit Alfabeta

Wibowo, I. G. P., Riana, G., \& Putra, M. S. (2015). Pengaruh Stres Kerja terhadap Kepuasan Kerja dan Komitmen Organisasional Karyawan. E-Jurnal Ekonomi Dan Bisnis Universitas Udayana, 5(1), 86-90

Yani, N. W. M. S. A., Sudibya, I. G. A., \& Rahyuda, A. G. (2016). Pengaruh WorkFamily Conflict Dan Stres Kerja Terhadap Kepuasan Kerja Dan Turnover Intention Karyawan Wanita. E-Jurnal Ekonomi Dan Bisnis Universitas Udayana, 5(3), 629-658

Yasa, I. G. R., \& Dewi, A. A. S. K. (2018). Pengaruh Stres Kerja Terhadap Kepuasan Kerja Dengan Motivasi Kerja Sebagai Vaiabel Mediasi. E-Jurnal Manajemen Universitas Udayana, 8(3), 1203-1229 https://doi.org/10.24843/ejmunud.2019.v08.i03.p02

Zorlu, K. (2012). The Perception of Self-esteem and Self-efficacy as Transforming Factors in The Sources of Role Stress and Job Satisfaction Relationship for Employee: A Trial of a Staged Model Based on The Artificial Neural Network Method. African Journal of Business Management, 6(8), 3014-3025. 